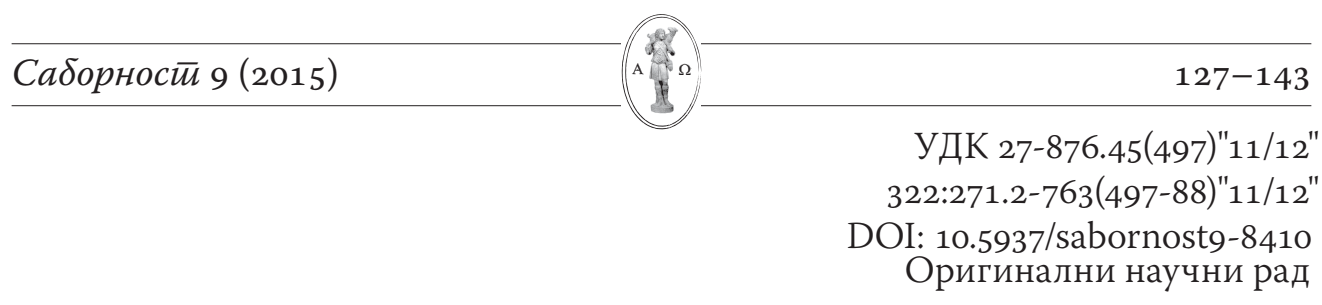

\title{
Радован Радић"
}

Хришћански културни центар, Београд

\section{Антибогумилска борба православних владара током XII и у другој деценији XIII вјека}

\begin{abstract}
: Богумилство је хришћанска јерес која свој огроман успон доживљава крајем XI и у првој половини XII вјека на југоисточном дјелу европског континента и у Малој Азији. Колико је Богумилство у једном одређеном временском оквиру представљало пријетњу државном поретку свједочи и ангажовање православних владара у циљу рјешавања богумилске кризе. Борба владара се огледава у сазивању државних сабора тј. синглитоса, на којим се јерес драстично кажњавала.
\end{abstract}

Key words: Богумили, антибогумилски сабор, синглитос, Василије Богумил.

$Б^{\circ}$ огумилство је хришћанска јерес која се појављује у Првом бугарском царству за врјеме владавине Петра I (927-970). Из периода Петрове владавине потиче и први званични антибогумилски текст. Рјеч је о тексту презвитера Козме познатом под називом „Бесједа против Богомила“. Он у овом опширном антибогумилском спису потврђује врјеме настанка јереси унутар Првог бугарског царства: „...у врјеме владавине православног цара Петра, у земљи бугарској појавио се један свештеник под именом Богумил..." (Т $\alpha \rho v \alpha v i \delta\rceil \varsigma, ~ 2005$, стр. 44-45). Наведено потврђује и нешто каснији одломак из Бориловог синодика, који датира из периода након 1211. го-

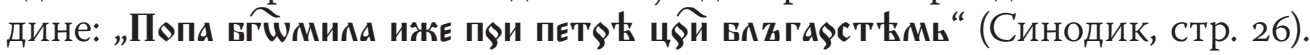
Међутим, Богумилство свој врхунац доживљава у Византијској Империји током XI и у првој половини XII вијека. Претходном свакако доприноси успон Империје у Х и XI вијеку, као и освајања огромних територијалних

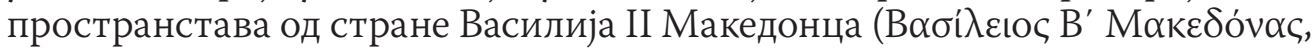
958-1025). Уласком унутар граница Империје Богумилство доживљава своју експанзију, што се може и потврдити и из текстова византијских

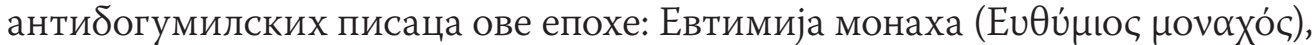

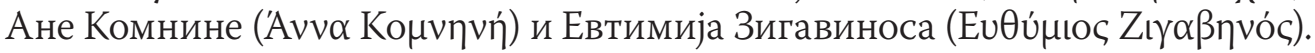

\footnotetext{
r_radovan@hotmail.com

1 „Беседа против Богомилите“
} 
Последњи писац у свом капиталном дијелу „Паноплија догматики“ (П $\alpha$ -

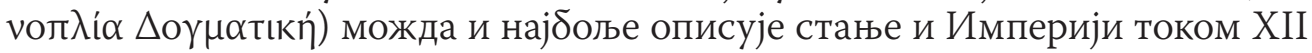
вијека: „...јерес је у сваком граду, земљи, области, напредује сада, и њени утемељивачи не престају заблуђивати најпростије мећу људима“".

Начин борбе православних владара против Богумилства гради се на државном сабору тј. скупштини или синглитосу (бúүк入птос), којим је, према правилу, управљао император, цар или велики жупан уз присуство званичних државних, као и црквених великодостојника. Одлуке антибогумилских сабора имају државни и општеобавезујући карактер. Претходно се може и потврдити из директног ангажовања војске при реализацији одлука сабора, гдје се у сва три примјера јеретици драстично кажњавају. На саборима је Богумилство окарактерисано као непријатељ Империје, односно државе.

Проблематичном се поставља улога владара током засједања антибогумилског сабора. Наиме, владар се у сва три примјера током засједања појављује у својству судије, на основу чега саслушава, савјетује се и коначно доноси пресуду. Претходно, наравно, проналази јако упориште у средњовјековном законодавству, гдје се у све три државе владар појављује као личност на врху државне лествице званичника са израженим владарским, законодавним и судским привилегијама. Наведено достиже свој изразити врхунац посебно у Византијској Империји гдје идеологија о владару - императору, божијем човјеку, који не подлијеже овоземаљским законима него само побожним тј. Божијим, налази јако утемељење током цјеле ромејске историје. Према истој император јесте судија, законодавац и једини тумач закона. Он има право постављати судије, те сам судити у случајевима од државне важности, као и доносити пресуде и помиловања. Такође, император има моћ тј. надлежност да сам мјења законе. У оргиналном латинском јустинијановом тексту се наводи „оно што владар заповједа има снагу закона“".

Фактор царске власти јесте одлучујући при рјешавању горућих црквених тема у предисихастичком периоду средњег вијека ${ }^{4}$. Уступање аутокефалије тј. самосталности одређеним областима Цариградске Патријаршије, које се налазе ван оквира Империје, одиграва се уз директно одобравање императора са или без гласања на синглитосу или издавањем званичног Томоса од стране Цариградске Патријаршије. Аутокефалија бугарске цркве у X вијеку јесте директна последица интервенције императора Романа Лека-

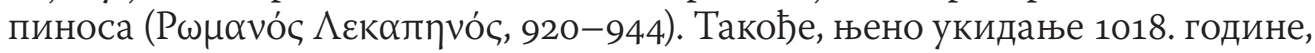
као и оснивање Охридске Архиепископије, последице су унутардржавне

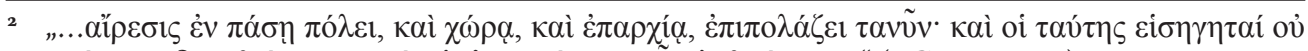

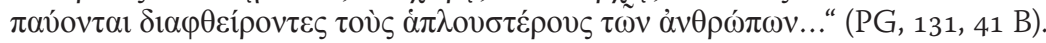

3 "quod principi placuit legis habet vigorem" (The Institutes of Justinian, 2007, I, 2, 6).

4 О односу српских владара према Цркви, писали смо и у Радић, 2013. 
политике Василија II Македонца. У последњем случају император са своје три одлуке - сигилија $(\sigma \iota \gamma i ́ \lambda \iota \alpha)$ и без писменог оглашавања званичне Цариградске Патријаршије, укида постојећу и оснива нову црквену организацију тј. Охридску Архиепископију. Свакако битан моменат за разумјевање комплетне ситуације јесте 1219. година и одлазак Светог Саве у Никеју. Светитељ при свом боравку у новој престоници Империје од самог Им-

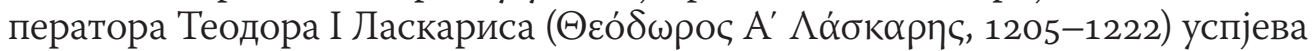

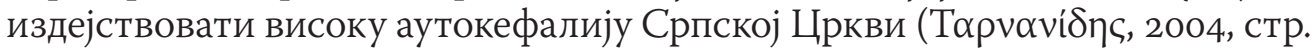
83). Са друге стране, на недостатак царске власти и надлежности, по питању случаја Светог Саве, у својој посланици се позива Охридски архиепископ

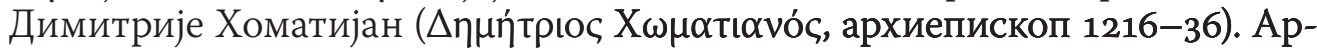
хиепископ подсјећа да Теодор I Ласкарис, након догађаја из 1204. године, и нема право изаћи у сусрет светитељу јер сам није сачувао „достојанство цјеловитости царства“". Хоматијан пишући ове редове подразумјева да право на цариградски престо има управо његов заштитник, ипирски де-

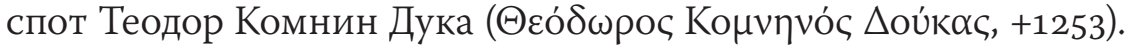

Антибогумилски сабори одржани у XII вјеку се увелико разликују по својој организацији од ранијих сазиваних по питању јереси. Наиме, раније утемељена пракса у Империји поводом појаве јереси јесте сазивање сабора на коме је предсједавао лично император док је тјело сабора састављено од црквених званичника из цјеле хришћанске васељене. Антибогумилски сабори су имали карактер чисто државног сазива уз присуство државних делегата, коме је могао или не слиједовати и црквени сабор. Наведено се може најбоље примјетити у случају Алексијевог сазива из 1110. године коме слиједује Ендимуса синод Цариградске патријаршије.

Атмосфера која се ствара доношењем одлука на саборима током XII вијека на балканском простору јесте антибогумилска. Богумили су осуђивани као непријатељи државе, који су урушавали до тада већ утврђени државни поредак. Такође, они су јерес која са непоштовањем говори о Христу и Богородици. Наиме, само одбацивање Христа као Бога, од кога лично испод фреске Сведржитељеве у трулу велелијепног храма Свете Софије а преко руку цариградског патријарха император при свом крунисању прима круну, за Ромеје јесте урушавање државног поретка.

Три су државна сабора антибогумилског карактера забиљежена у историји. Повод за сазивање сваког од њих јесте експанзија Богумилства у појединим областима или чак престоници државе. Експанзија Богумилства у престоници Империје је и разлог сазивања синглитоса у Цариграду, 1110. године од стране императора Алексија I Комнина (А $\lambda \dot{\varepsilon}-$

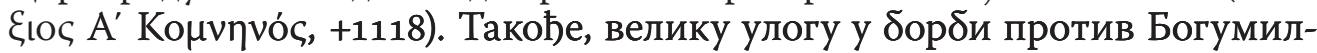

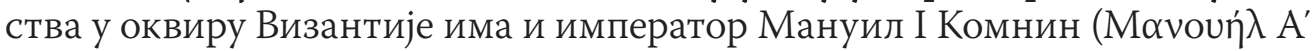
Конvұvós, 1143-1180), на чију иницијативу се 26. фебруара 1147. године у

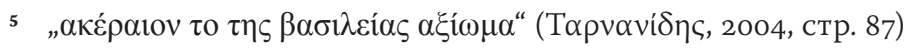


Палати Влахерни одржава Ендимуса синод, који и разрјешава патријарха

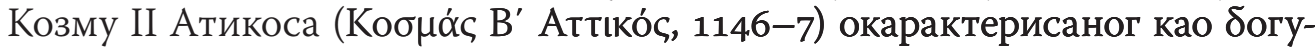
мила. Исти император пружа и сву несебичну помоћ епископу Цариград-

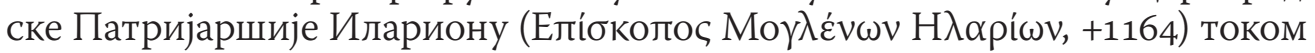
његове борбе са Богумилством у надлежној му епископији у Моглену

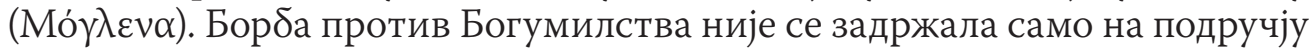
Империје. Са првим назнакама Богумилства у Рашкој, велики жупан Стефан Немања (+1199), прије 1180. године, у Расу организује државни сабор који ће имати за циљ неутрализацију јереси. Такође, у Бугарском царству, 1211. године, цар Борил (+1218) поводом јачања јереси Богумилства окупља једно огромно тјело сабора.

Алексијев антибогумилски сабор из 1110. године јесте први ове врсте у Империји, али и цјелом православљу, и као такав је послужио као снажан подстрек како каснијим византијским државним и црквеним вођама тако и српским и бугарским владарима на Балканском полуострву. Утицај антибогумиског сабора из 1110. године на балканске владаре се можда и најбоље огледава у Бориловом синодику. Преводилац синодика наводи да у његовом тј. бугарском царству, прије 1211. године као и прије његовог антибогумилског сабора, није одржан православни сабор ове врсте: „п९ЖжАє

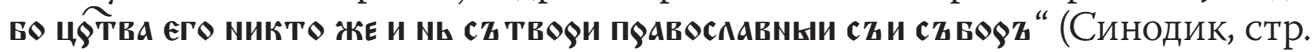
51). Са друге стране, јасно је да је цар Борил добро упознат са Алексијевом ठорбом против Богумилства ठаш као и ликом начелника јереси у Империји, Василијем Богумилом, који је у његовом синодику и уврштен у листу ана-

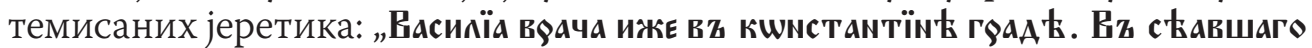

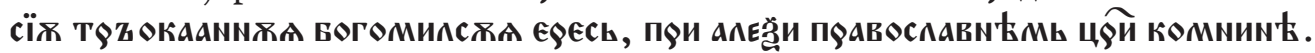
ПмаӨема." (Синодик, стр. 30-31). Напослијетку, цар Борил налаже превод синодика са грчког на бугарски језик у који ће са осталим великим православним саборима бити уврштен и овај његов антибогумилски (Синодик, стр. 51).

Стефан Немања је баш као и цар Борил имао значајан увид у византијску антибогумилску борбу током XII вијека. Сам је након своје предаје у руке императора Мануила Комнина одведен у Цариград. Тамо је за један одређени временски период, након 1172. године, смјештен у западном дијелу града у манастиру Евергетиде ( риграду се везује за период када је Богумилство у Империји доживљавало свој крах. Рјеч је о временском периоду након смјене са трона цариградских патријараха-богумила Козме II Атикоса, као и периоду након осуде највећег поборника Богумилства у престоници, кападокијског монаха

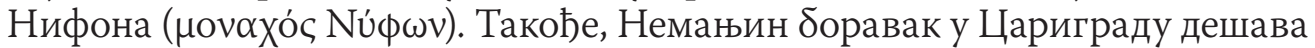
се након смрти великог антибогумилског борца у македонској области, епископа Илариона (Радић, 2015, стр. 34-39). 
Чињеница је како постоји изразит утицај Алексијевог антибогумилског сабора на касније православне владаре, како византијске тако и бугарске и српске. Међутим, податак који привлачи пажњу јесте тај да у поставци сабора постоји врло битна разлика у односу на ону из 1110. године. Разлика се прије свега односи на присуство или не оптужене стране, у овом случају јеретика тј. Богумила, као и њихово саслушање на сабору. Ово се прије свега односи на Немањин сабор из Рашке на коме, слиједујући свједочанство његовог живописца, краља Стефана Првовјенчаног (+1228), Богумили тј. осумњичени нису били присутни. Сасвим је друга ситуација забиљежена на Алексијевом сабору из 1110. године гдје је био лично присутан првоосумњичени, у Империји начелник јереси, љекар Василије „...и доиста је представљен Сатанин врховни вођа Василије, одијелом монах, испијеног лица, дуге браде, дубоке старости, који са непоштовањем располаже на многе начине“. Такође, записано свједочанство из синодика нам потврђује да су Богумили били присутни на Бориловом сабору из 1211. ГОДИНе: „ШNИ ЖЕ ОУПОВИТИ Ц९

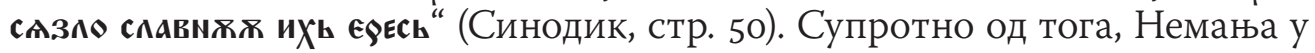
Расу одржава свој антибогумилски сабор гдје након саслушања свједока и донесене тешке одлуке шаље војску на мјеста где су претходно лоцирани Богумили: „посла на њих војску, наоружану од славних својих..." (Првовенчани, 1988, стр. 71). Немањина акција, у односу на друга два случаја, се односи на шире масе Богумила. Велики жупан јеретике драстично кажњава. Колики је био успјех Немањине реакције на успон Богумилства најбоље свједочи његов наслиједник на рашком пријестолу Стефан Првовијенчани: „И сасвим искорени ту проклету веру, да се и не помиње никако у држави његовој“ (Првовенчани, 1988, стр. 72).

Додатну пажњу привлачи улазак и откривање Богумилства унутар граница једне државе. Дијеловање јереси у наведеним балканским државама се према правилу открива након како великих територијалних тако и промјена у структури државне власти. Проширивање своје власти на један огроман дио европског али и азијског континента од стране Василија II Македонца повољно утичу на брзи успон Богумилства у Империји. Јерес је претходно лоцирана у Првом Бугарском царству како од стране бугарских власти тако и званичне Цариградске Патријаршије․ Међутим, нова стварност, пораз бугарске војске код Драча 1018. године (Острогорски, 1996, стр. 295) као и присвајање територија Империји, позитивно утичу на успон Богумилства. За врло кратак временски период Богумилство се може сусрести у Кападокији, Смирни, Фригији, Акмонији, Јерусалиму па

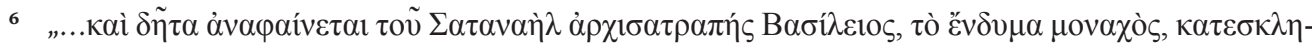

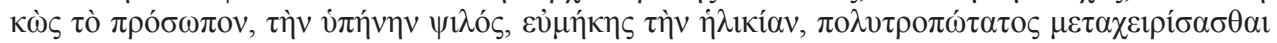
$\tau \eta ̀ v ~ \alpha ̉ \sigma \varepsilon ́ \beta \varepsilon 1 \alpha v^{\prime \prime}(\mathrm{PG}, 131,1169 \mathrm{C})$.

7 Гледај писмо Цариградског патријарха Теофилакта Лекапиноса упућено бугарском цару Петру I. 
чак и престоници Империје - Цариграду. О наглом успону Богумилства у Империји, у првој половини ХІ вјека, свједочи и црквени антибогумилски писац тога доба монах Евтимије из Цариградског манастира Перив-

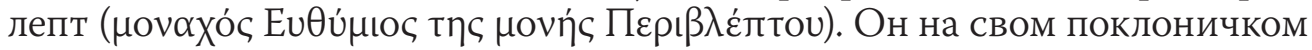
путовању за Свету Земљу, на своје запрепаштење, за сапутника има управо монаха Богумила: „Десило ми се некада да сам за сапутника имао овог безбожног, изглед је имао монаха..." Такође, каснији антибогумилски писац

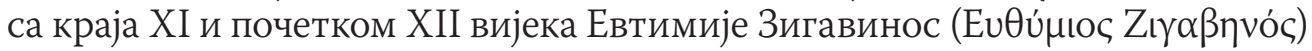
слаже се са временом настанка јереси: „Јерес Богумила није много прије наше генерације настала, била је дио Масалијанаца..."9

Идентична ситуација се одиграва у Бугарском Царству. Цар Калојан (1197-1207) у своју корист вјешто преусмјерава позитивну климу на европској политичкој сцени. Нагли успон папе Инокентија III (Innocentius III, +1216) и од његове стране организовање европских владара у нови поход на Свету Земљу под заставом Крста као и немоћ Византије након смрти императора Мануила, позитивно утичу на успон Бугарског царства. Калојан 1204. године, након интезивне преписке са Инокентијем, од папског изасланика је миропомазан и крунисан док црквену организацију у Бугарској уздиже у ранг Патријаршије. Са друге стране, на рачун Империје проширује своје територије, које су се протезале од града Сирмиума и Београда са једне стране све до области Тесалија и Тракија испод града Сереса и Адрианупоља са друге стране. Калојан у својим војним походима долази и до града Солуна. У Калојановом и у наставку Бориловом царству након проширивања територија налазе се дијелови у којима је историјски потврђено дејство Богумилства. Под наведеним територијама прије свега подразумјевамо Тесалију и Македонију. Наиме, у Моглену, у области Македонија, борба са Богумилством води све и до уснућа помињаног епископа могленског Илариона, у седмој деценији XII вијека, док се њихово присуство у Тесалији наводи у дијелу Симеона архиепископа града Со-

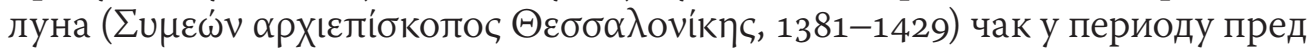
турског ропства. Писац синодика успон Богумилства у Бугарском царству ставља у оквире након доласка на власт цара Борила, 1207. године.

Ситуација у Рашкој, по питању Богумилства, доживљава нагли заокрет тек доласком на власт великог жупана Стефана Немање. Промјене на државном врху сигурно негативно утичу по Богумилство, које је присутно у Рашкој и прије Немањиног доласка на власт. На претходни закључак нас доводи чињеница да је врло кратак временски период између жупановог доласка на власт, 1168. година, и одржавања антибогумилског сабора, прије

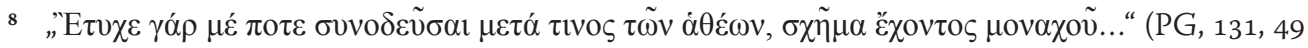
A).

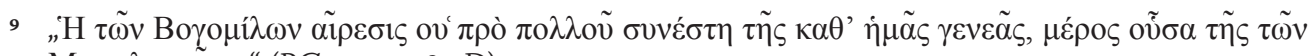

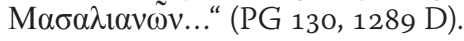


1180. године. Примјера ради, у Византији главна окосница борбе против јереси се завршава већ половином XII вјека док се у периоду Немањине

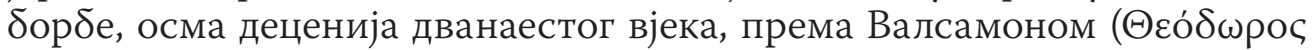
В $\alpha \lambda \sigma \alpha \mu \omega \dot{v},+1195)$ свједочанству Богумилство већ налази у осјетном паду (Voellus, Justellus, 1661, стр. 1042). Такође, према Немањином живописцу, територијално проширење Рашке одиграва се тек након његовог антибогумилског сабора и промјене гарнитуре власти у Империји са којом велики жупан има изразито лоше односе (Првовенчани, 1988, стр. 70-73). Наравно, потребно је истаћи и то да на новог рашког жупана утиче комплетна антибогумилска клима XII вијека, са којом је он као што смо и примјетили одлично упознат. Такође код Стефана Немање, сасвим супротно у односу на његову браћу, јесте присутна изразита ревност ка чистоти православља. Наведено се потврђује на много мјеста у његовом житију али и у великом броју храмова, жупанових задужбина.

\section{1. Алексијев антибогумилски сабор}

Богумилство у Империји крајем XI и почетком XII вијека јесте јеретичка групација у експанзији. Дијеловање јереси откривамо како у европским тако и у малоазијским областима Византије. Током наведеног временског периода Богумилство јесте јерес добро организована са јако развијеном структуром управе. За Богумиле у Империји влада опште мишљење да су живјели по великим манастирским Лаврама, те да су облачили монашко одијело управо да би придобили нове чланове јереси ${ }^{\mathbf{1 0}}$. Претходно нам потврђује и монах Евтимије, можда и кључни свједок богумилског дијеловања у пред Алексијевој епохи „...глуме злобно злобници Хришћанство, и монаха изглед, и свештенство, и Свето Писмо као мамац у устима носе..." Одбацивање православних догмата, поготово о Христу, Духу Светом као и Богородици, непризнавање православних храмова, као и спорна учења о стварању свјета и човјека од стране Сатанаила, утичу на то да су Богумили у Империји врло брзо окфалификовани као јерес чије се учење не заснива на вјеровању Бога него напротив у Сатану: „Ови не поштују Бога творца неба и земље, нити Богородицу... вјерују пак и поштују овоземаљског господара, који је Сатана“12.

10 Одавде и произилази у византијским изворима велики број примјера монаха - Богумила, најпознатији од којих су: примјер Евтимијевог ученика, његовог сапутника за Јерусалим, четворице учитеља из манастира Перивлепт, Јована Тзуриласа, Василија Богумила, двојице епископа Кападокијаца, монаха Нифона, игумана Атиногенус Петра, Константина Хрисомалоса, али и патријарха Косме (Опширније: Радић, 2015).

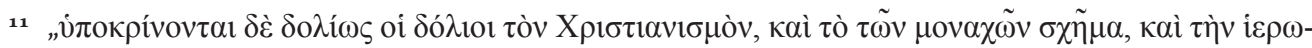

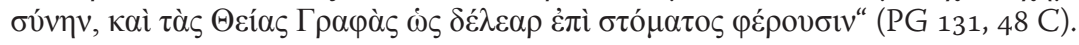

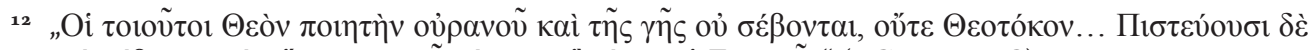

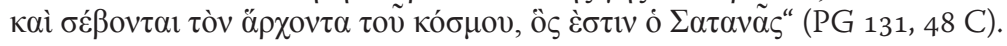


134 | Радић, Р., Анйибоїумилска борба йравославних влаgара..

У периоду Алексијеве владавине, Богумилство се у Империји налази на свом врхунцу. Главни свједок ове епохе, историчарка Ана Комнина ('Аvv $\alpha$

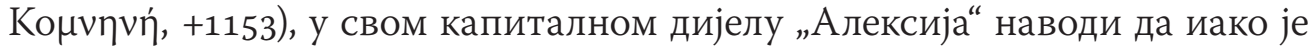
јерес производ новијег датума, становници Империје су ипак одлично упознати са њеним дијеловањем „...док је глас о Богумилима већ свугдје распрострањен"13. С обзиром на чињеницу да су Богумили угрожавали постојећи државни поредак, император Алексије својим сарадницима налаже задатак који се односи на проналазак вође Богумилства у Империји, љекара Василија Богумила. Врло брзо је вођа Богумилства у Империји приведен пред императора. Занимљива чињеница коју нам у свом дијелу излаже Ана Комнина односи се на изглед Василија Богумила. Према њеном свједочанству Василије је одијевен у монашко одијело „...Сатанин врховни вођа Василије, одијелом монах..." ${ }^{4}$

Посебну пажњу привлачи дијалог, који је и послужио као разлог и увод у Алексијев сабор - синглитос. Наиме, при доласку Василија Богумила у Палату, император Алексије се послужио лукавством. Да би детаљније истражио Богумилство, које је у Империји „нова врста јереси“15 и за које Ромеји и немају једну ширу представу, император се са Василијем упушта у једну општу богословску расправу. Император му се, између осталог за врјеме гошћења, и повјерава како његов ученик жели постати „...кроз све се претваравши да је ученик његов хтио постати; не само он сам него и његов брат севастократор Исаак" ${ }^{\text {"16. }}$. Разговор се одвија у једној засебној просторији, преграђеној завјесом, у којој се налази Алексије, његов брат севастократор Исак као и Василије Богумил. Последњи, током дугог и опширног разговора, види своју велику прилику те настоји слушаоце, рођене у Порфири, убједити у Богумилство. Након цјелог чина у коме Василије чак открива и усторјство своје јереси, као и комплетно њено учење, завјеса која дијели просторију скида се док се иза ње налази присутан комплетан византијски државни, војни као и црквени врх. Занимљив податак јесте да цјело Василијево излагање биљежи брзописац из Палате. На основу тог текста касније, а на прједлог императора Алексија, византијски учени монах Евтимије Зигавинос саставља поглавље дијела „Паноплија Догматики“ које се односи на Богумиле. На основу свог излагања, Василије Богумил изазива оштар гњев код званица присутних у Палати, који су као што из извора можемо закључити предлагали најоштрије могуће казне:

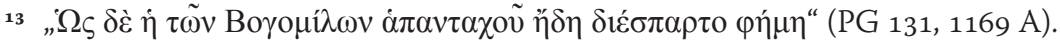

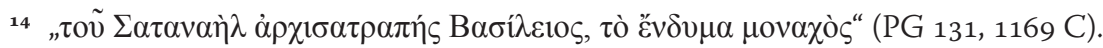

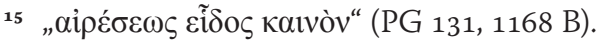

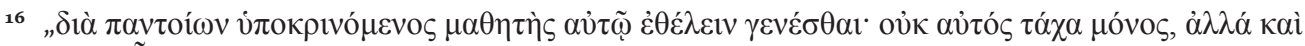

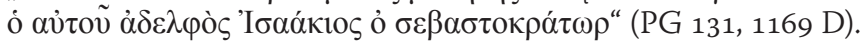


„и на ломачу и бичевање као и других хиљаду облика смрти обећавајући предлагаше“"

Из текста Ане Комнине можемо закључити како се на иницијативу императора Алексија исте 1110 године сазива синглитос. Засједање синглитоса је и повод окупљања у престоници Империје многих бројних Ромеја, државних али и црквених званичника „...многи су овом приликом били присутни на сједници - синглиту и светом синоду, и од ових Назиреја великана ријечи учествовали су говорници“"18. Разлог окупљања синглитоса врло брзо добија антибогумилски карактер. Наиме, иако цјели богумилски случај почиње Василијевим салушањем, убрзо се суђењу придружују и остали Богумили, чија имена љекар открива током разговора са императором. Овде се прије свега мисли на постојање дванаесторице замјеника, познатих под карактеристичним називом дванаест апостола. Одлуке антибогумилског синглитоса из 1110. године јесу катастрофалне по Богумилство. Василије Богумил заједно са дванаесторицом својих апостола, као и другим присталицама осуђује се на јавно спаљивање на ломачи. Наиме, одређени број Василијевих следбеника, након понућеног избора и одбијања повратка у Хришћанство, бива осућено са непоколебљивим љекаром Василијем. Чин казне се одржава пред мноштвом Ромеја на Цариградском Хиподрому. Одлуку о тешкој казни за Богумиле при гласању подржава и Император Алексије „...и император је гласао исто“19. Са друге стране на свом засједању Ендимуса синод са четрнаест анатематизама Богумилство изопштава као јерес (PG 131, 40-48).

Занимљив податак и уједно врједан пажње а који је везан за Василијеву пресуду јесте тај да иако је иста плод државног византијског врха, њу једнодушно прихвата како државни, тако и црквени врх са патријархом

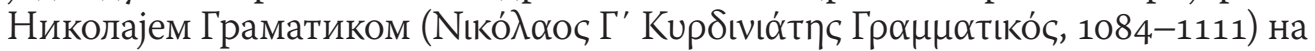
челу, али и угледни монаси из реда Назиреја „Тако су Василија сви присутни на светом синоду чак и учени Назиреји, и овај тадашњи патријарх Николај као истинитог поглавара јереси и уопште не обраћеног и достојног ломаче процјенили“. Међутим, рјеч је о личној подршци наведених званичника политици императора Алексија а не о званичном ставу Цариградске патријаршије, што се може потврдити и из низа засједања антибогумилских сабора током XII вијека.

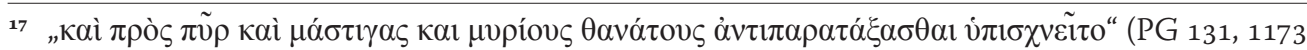
A).

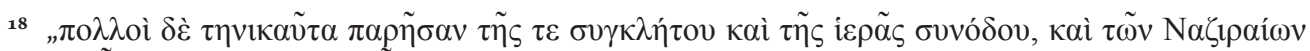

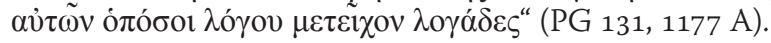

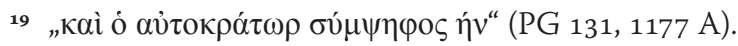

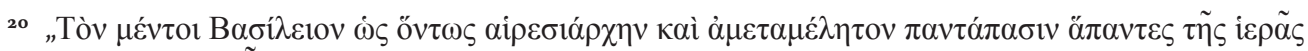

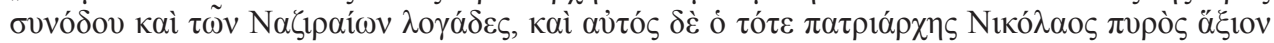
ह̌к 


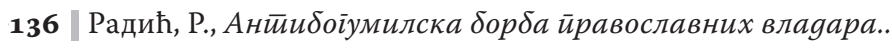

Антибогумилски сабор императора Алексија из 1110. године јесте снажан подстрек каснијим како византијским црквеним и државним тако и српским и бугарским вођама. Алексијев синглитос - сабор јесте увод у једну много ширу борбу против Богумилства у окриљу Цркве, на територији цјеле Империје, што нам и потврђују велики број засједања Ендимуса синода током пете деценије XII вијека (Радић, 2015, стр. 31-36).

\section{2. Антибогумилски сабор великог жупана Стефана Немање}

Откривање Богумилства у Рашкој јесте повод брзог сазивања једног, сходно историјском извору, не малог тјела сабора, којим управља велики рашки жупан Стафан Немања. Податке о антибогумилском сабору добијамо из житија Стафана Немање, писаних од стране његовог сина и наслиједника на рашком пријестолу - Стефана Првовјенчаног. Нажалост, једини писац и савременик ових догађаја, наведени писац и владар, у први план ставља побожност и ревност свог оца, занемарујући значајне историјске чињенице а које се односе на рад сабора. Овде прије свега подразумјевамо имена протагониста ових догађаја као и годину и мијесто одржавања антибогумилског сабора. Такође, рашке области у којима Богумили дијелују, као и имена њихових вођа из текста житија нам нису доступна. Стога нам остаје непознаница велики број догађаја везаних за Немањин историјски значајан антибогумилски сабор.

Немањин живописац врјеме сазива сабора поставља између жупановог доласка на власт, 1168. године, и промјена на византијском пријестолу након смрти великог византијског императора Мануила Комнина, 1180. године (Првовенчани, 1988, стр. 69-73). Према Првовјенчаном, у Цариграду се појављује „други цар“, за врјеме чије се владавине односи Византије и Рашке налазе можда и на најнижом историјском ступњу (Првовенчани, 1988, стр. 72). Подаци које нам писац пружа јесу доста уопштени и непрецизни, што се може и примјетити и из чињенице неименовања новог византијског императора. Такође, проблем је очевидан код наведених градова освојених од стране Немање. Рјеч је о областима и градовима припојеним Рашкој у деветој деценији XII вијека, за вријеме које се у Империји мијењају чак три владара. Под „други цар“ одговара историјски профил Андроника I

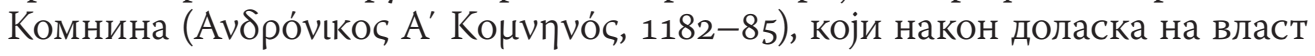
у Византији има високе прохтјеве, те настоји повратити, након Мануилове смрти, изгубљену државну равнотежу те поново придобити одузете

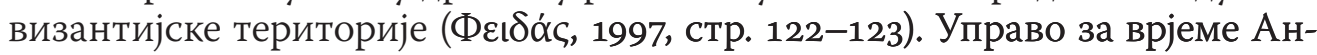
дроникове владавине образује се савез између Угарске и Рашке, последица чега су изузимање из ромејске надлежности Београда, Ниша, Браничева и Сардике (Острогорски, 1996, стр. 374). Коначно, претпоставка је да се Немањин антибогумилски сабор одржава у периоду између његовог 
повратка из Цариграда, гдје је одведен 1172. године, и смрти великог ромејског императора Мануила Комнина.

Занимљив податак и уједно врједан додатне пажње јесте тај да краљ Стефан у своме спису као назив за јеретике не користи већ општеприхваћени израз Богумил. Наведени израз, без сваке сумње, поготово у XII вијеку, налази своју ширу примјену у свим православним срединама, чак и у Византији. Колико је овај израз устаљен најбоље свједочи и његово уврштење у званичну црквену терминологију истог вјека (Радић, 2015, стр. 43-45). Наведено потврђују византијски антибогумилски сабори из пете деценије XII вијека, гдје да би се дефинисало погрешно учење појединих монаха - Ромеја користи се израз „Богумила вјеровање ${ }^{\star_{\mathbf{2 1}}}$. Насупрот том, Првовјенчани у свом тексту за Богумиле користи придјеве као што су: „лукава“, „триклета“ и „проклета“ јерес.

Међутим, у дијалог који се одвија између жупана Немање и његовог правовјерног војника, Првовјенчани уноси врло прецизне податке о јеретицима. Насупрот Немањи, поменута јерес погрешно учи о Христу, Богородици као и светитељима (Првовенчани, 1988, стр. 70). Богумили јесу управо карактеристични по свом савелијанистичко-манихејском ставу по питању Христологије, док за исте учење о светитељима јесте блиско повезано са демонологијом. Извијештај о рашким јеретицима битно допуњује и касније свједочење на сабору, кћерке једног од Немањиних велможа. Она великом жупану, али и окупљеним на сабору потврђује како јеретици не служе Христу него напротив самом Сатани. Давање божанских стваралачких особина Сатани јесте врло својствено Богумилима, што нам и потврђује и Зигавинос у свом одломку посвећеном њиховом учењу: „... створићу и ја друго небо, као други бог, и све наредно што следује..." Према истима Сатанаил је стваралац свјета и тјела човјековог док је дух животни дијело благог Оца.

Без сваке сумње да је рјеч о Богумилима у тексту краља Првовјенчаног, потврђује временски оквир јеретичког дијеловања баш као и карактеристике које се приписују јеретицима на овом сабору а које се у потпуности подударају са описом Богумила већ прихваћеним у Империји: „Ови не поштују Бога творца неба и земље, нити Богородицу... вјерују пак и поштују овоземаљског господара, који је Сатана“"23.

Организација сабора припада великом жупану Стафану Немањи. На његов позив у рашкој престоници се окупља комплетан државни врх, састављен од његових велможа, уз присуство епископа Евтимија, као и

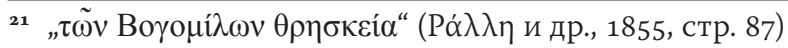

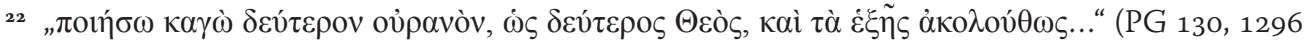
D).

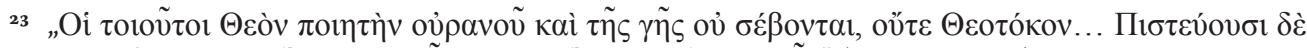

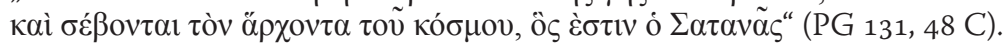


великог броја игумана и монаха (Првовенчани, 1988, стр. 70). Велики жупан у свом обраћању настоји убједити присутне како је богумилска јерес подједнако погубна и раздорна за јединство, како државно тако и црквено, управо као некад Аријанство. Међутим, из текста се може примјетити да се током рада сабора ствара јака опозиција, која се и није слагала са ставовима великог жупана: „И док је говорио овај Свети, и док је била велика препирка..." (Првовенчани, 1988, стр. 71). Немањи је било потребно једно јако свједочанство које би преокренуло рад сабора у његову корист. Изнанада, на сабору се појављује кћерка једног од жупанових блиских сарадника. Она, која је у прошлости из незнања испрошена и удавана за Богумила, доноси страшно и за окупљени сабор поразно свједочанство. Исто се односи на горе наведено служење Сатани од стране Богумила (Првовенчани, 1988, стр. 71).

На овом дијелу рада битно је истаћи како су Богумили заиста давали божанске особине Сатанаилу, који је према истима и био старији син Божији. Такође, имају и своје интерне обреде, што је и записано у дијелу Евтимија монаха. Међутим, обред посвећен Сатанаилу (PG, 122, стр. 832 В)

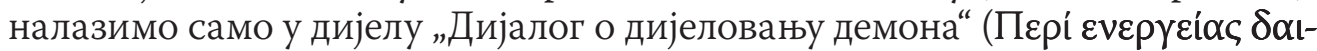

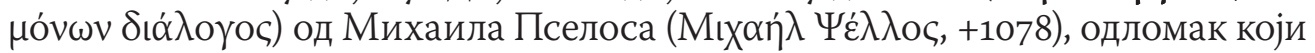
је уједно и оспораван од стране великог броја историјских истраживача.

Заиста, потресно свједочанство Немањиног свједока „ломи“ сабор који и по питању Богумила заузима званичан став „а Свети, изведав ову пред сабор свој, сабран против те лукаве јереси, изобличи кривовјерје њихово“ (Првовенчани, 1988, стр. 71). Након савјетовања са државним врхом, али и црквеним званичницима доноси се одлука о статусу Богумила. Иста подразумјева ангажовање војске у областима у којима су лоцирани јеретици.

Посебну пажњу у Стефановом тексту привлачи помен епископа Евтимија „...и саветова се са светитељем својим Јефтимијем..." (Првовенчани, 1988, стр. 71). Краљ Првовјенчани у своју повијест, као што смо већ споменули, не уврштава имена, хронологије нити мјеста од историјске важности уз изузетак епископа Евтимија кога у вези са антибогумилским сабором наводи чак два пута. Први помен епископа је при сазивању сабора, док је други при савјетовању о даљој судбини Богумила. Евтимије је свакако личност високопозиционирана у рашком средњовјековном друштву. Наведено се може закључити и из краљевог текста гдје и поред великог броја велможа, игумана и монаха само њега ословљава са „свој“ тј. његов архијереј, али и називом „светитељ“ (Првовенчани, 1988, стр. 70-71). У овом дијелу рада од непроцењљиве врједности јесте истаћи црквено-правни статус епископа Евтимија. Под црквено-правни статус подразумјевамо географску надлежност којој епископ припада, али и подређену му епископију, која му је од званичне цркве повјерена на управљање. Стефан Немања пред сами крај своје владавине, у својој држави има чак шест епископских сједишта, 
подређених Охридском Архиепископу или архиепископији „цјеле Бугарске“. Међутим, у временском периоду одигравања антибогумилског сабора његова држава је знатно мањих размјера и у њој се налази једно сједиште и то сједиште Рашког епископа. Сходно томе, високопоштовани епископ Евтимије јесте подређен архиепископу Охридском, тј. припадник Цариградске Патријаршије. У самом рангу тј. поретку унутар архиепископије, епископ Рашки није заузимао престижно рангирану позицију. Сходно званичним каталозима Цариградске Патријаршије (Notitia 13) епископ Рашки је седамнаести епископ по рангу у оквирима Охридске Архиепископије (Darrouzes, 1981, стр. 371-372).

Казна за Богумиле била је жестока. Војска која је ангажована јесте немилосрдна. Међутим, за разлику од византијског антибогумилског сабора, одлуке Немањиног нису подразумјевале смртне казне. Ово се најбоље потврђује из случаја начелника Богумилства у Рашкој који је, како нас Првовијенчани обавјештава, лоциран и ухваћен док је кажњен одстрањењем језика. Наравно, доста ригорозније мјере примјећујемо у Византији гдје је начелник јереси љекар Василије јавно спаљен на ломачи. Остале мјере против Богумила подразумјевају заплијену имовине, кажњавање блажим казнама, спаљивање књига, али и протјеривање из државе.

\section{3. Антибогумилски сабор цара Борила}

Борилов антибогумилски сабор се одржава у специфичном тренутку по балканске православне државе. Православље се налази у никад лошијој ситуацији док са Запада, под организацијом ученог папе Инокентија III, огромна војска са знаком Крста осваја како православне тако и исламске територије. Управо пред овим налетом 1204. године пада и престоница Византије, Цариград, док се Империја дијели на три доста мања царства. Папа Инокентије води своју искусну политику која се односи на повратак Свете Земље под окриље Хришћанства, али и уједињење цјеле Цркве, при чему би остале традиционалне источне патријаршије биле потчињене Риму. Почетком XIII вијека Инокентије води опширну преписку и преговоре како са православним владарима тако и са црквеним вођама на југоисточном дијелу европског континента, али и у Малој Азији. У временском периоду између 1203-1204, папа Инокентије на тему уједињења

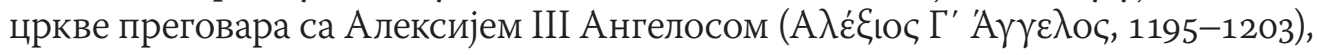
Калојаном Бугарским, Василијем Трновским архиепископом, архијерејима и монасима у Рашкој тј. Србији, као и монасима у Босни. Уједињење цркве наравно подразумијева подчињавање православних патријаршија Светој Римској столици. Наведено, у својој посланици из 1204. године, на специфичан начин папа Инокентије и образлаже византијском императору Алексију Ангелосу: „...и ћерко враћај се мајци, и Црква Цариградска, 
140 | Радић, Р., Анӣибойумилска борба йравославних влаgара..

која је апостолска катедра, много година вјерног дуг одбија..." ${ }^{24}$ Сходно папском излагању, у случају прихватања уједињења, исти византијском императору гарантује и државни опоравак као и самосталност: „Сходно томе, у страху Божијем и апостолске катедра достојанство Империје твоје биће снажно, не уназађено, баш као што је сада уназађено, него у његовој снажној и чврстој сигурности..." ${ }^{\text {"25 }}$

Римокатоличко станиште о првенству Рима у односу на остале традиционалне источне патријаршије има додатну потпору у историјској теорији о апостолу Петру оснивачу Римске столице као и спорном мјесту из прве посланице Коринћанима, које и сам Инокентије користи овом приликом: „и као први од апостола прозван је Петар, и за кога каже апостол 'Петар бјеше Христос'..." ${ }^{\prime 6}$

Успон Бугарског царства одиграва се за врјеме владавине династије Асена. Њен најзначајнији представник јесте ठез сваке сумње цар Калојан (1197-1207). Он је захваљујући својој антивизантијској политици као и због тешког пораза нанијетог Ромејима врло брзо стекао назив Ромеоубица. Калојан, за разлику од других балканских владара, не одбија понуду папе Инокентија тако да већ 1204. године обнавља Трновску патријаршију, као унијатску, док се од стране папског изасланика миропомазује и прима царску круну. Границе своје државе проширује на рачун својих првих сусједа, поготово Византије, тако да су његове границе према Византији стизале чак и до града Солуна. Његовим освајањима унутар граница његове државе присједињује се Моглена као и дијелови Тесалије гдје је историјски потврђено дијеловање богумилских групација. Цара Калојана на бугарском прјестолу наслјеђује Борил, који за разлику од њега врло брзо губи огромна територијална пространства. Овде прије свега мислимо на Београд, Браничево, Ниш као и дијелове Тракије. Између осталих ратних похода, цар Борил ратује и са Солунским краљевством.

Цар Борил на страницама Црквене историје остаје записан због организације свог антибогумилског сабора као и у наставку одлуке о преводу „Синодика“ са грчког на бугарски језик. Наиме, 11. фебруара 1211. године, због огромног успона богумилске јереси у Бугарском царству, Борил окупља свој антибогумилски сабор. За исти, нажалост, писац Синодика

${ }^{24}$ „et filia revertatur ad matrem, et Constantinopolitana Ecclesia, quae apostolicae sedi multo tempore devotionis..." (PL 215, 259 B).

25 „Siquidem, si in timore Domini et apostolicae sedis reverential imperium tuum fuerit roboratum, non vacillabit, sicut hactenus vacillavit, sed in illius petrae soliditate fundatum..." (PL $215,260 \mathrm{~A})$.

26 „a qua princeps apostolorum dictust est Petrus, et de qua inquit Apostolus: Petra autem erat Christus" (PL 215, 260 A). Да је рјеч о камену или стјени а не о апостолу Петру потврђује изворни грчки текст прве посланице Коринћанима у коме се $\bar{u} \bar{u} p a$, са првим малим словом односи на именицу камен а не на лично име у овом случају име апостола Петра

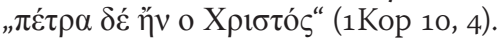


пропушта навести тачну локацију засједања, мјесто чега напросто наводи да сабор засједа у простору једног од његових тј. Борилових великих храмова (Синодик, стр. 49). Сабор је састављан од свих бугарских велможа као и архијереја који су се у том тренутку налазили под Бориловом власти. Такође, сабору су присуствовали велики број монаха, свештеника као и вјерног народа (Синодик, стр. 49). Занимљив податак јесте да тек након окупљања сабора и преузимања мјеста са кога је предсједавао, Борил издаје наредбу о привођењу јеретика. Од овога тренутка Борилов сабор преузима елементе византијског или Алексијевог сабора. Наиме, сам цар са Богумилима води једну опширну богословску дискусију, при којој јеретици Борилу откривају многа непозната мјеста свога устројства али

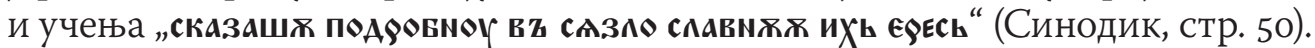
Наравно, писац Синодика пропушта додатно изложити учење Богумила. Међутим, у дијелу који се односи на анатемизме могу се пронаћи основне црте богумилског учења, управо као што је она о зачетку новог живота тј. дијета под дијеловањем Сатаниним (Синодик, стр. 28). На крају разговора, сходно запису из Синодика, богумилско учење је на основу Светог Писма изобличено. Из текста Синодика може се закључити како је Богумилима дато право избора, на основу кога један дио њих се враћа саборној цркви

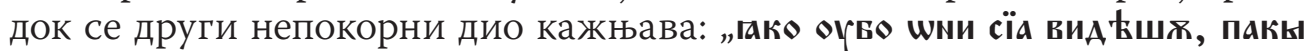

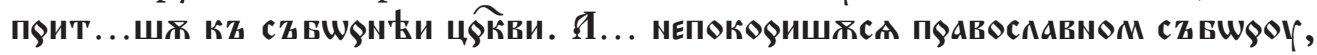

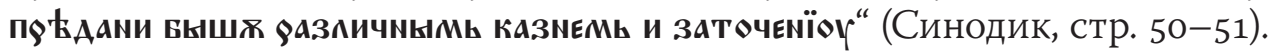

Од непроцјењљиве је врједности дио текста који се односи на имена истакнутих учитеља или вођа богумилске јереси. Текст јесте анатемизам и налази се на педесет и другој страници Синодика, након поглавља о сабору. Анатемизам јесте карактеристичан пошто писац издваја шест имена Богумила, најзначајнијих ученика свештеника Богумила, од осталих његових ученика и истомишљеника (Синодик, стр. 52). Рјеч је о Михаилу, Теодору, Добрје, Стефану, Василију и Петру. Да је ријеч о посебној групацији особа тј. лица са посебним статусом унутар јереси свједочи и помен Василија, који је без сваке сумње љекар Василије Богумил осуђен од стране императора Алексија Комнина 1110. године. Свакако, византијски извори обилују именима Богумила међутим, од истих се само Василије Богумил ословљава као „...учитељ и врховни заповједник богумилске јереси“27. Писац свакако узима у обзир јеретике како у Првом Бугарском царству тако и оне у Империји, подсјећамо како су бугарске области од 1018. године до периода након смрти Мануила Комнина 1180. године неодвојиви дио Империје.

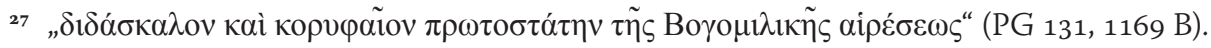


142 | Радић, Р., Анӣибоїумилска борба ирравославних влаgара..

\section{Литература}

Борилов Синоgик. Националната библиотека „Св. св. Кирил и Методий“ Sp. 289.

Voellus, G., Justellus, H. (1661). Bibliothecae Ivris Canonici Veteris, tomus II. Lutetiae.

Darrouzes, J. (1981). Notitiae Episcopatuum Ecclesiae Constantinopolitanae. Paris: Institut Francais D'Etudes Byzantines.

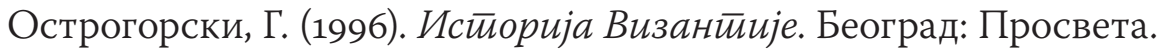

Радић, Р. (2013). Велики црквени раскол и његове последице на Балканском полуострву - XI вијек у Зети. Улога српских владара у оснивању

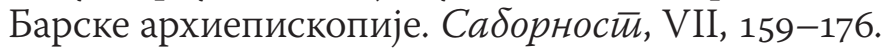

Радић, Р. (2015). Визанйија и боіумилстиво. Београд: Бернар.

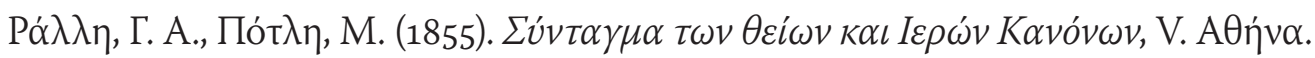

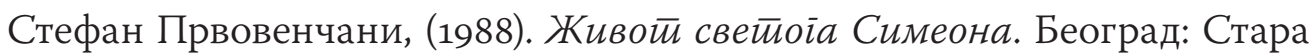
српска књижевност.

The Institutes of Justinian. (2007). New Jersey: The Lawbook Exchange, Ltd.

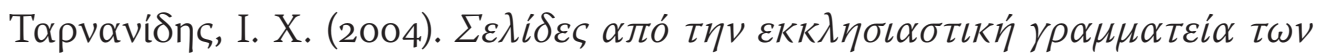

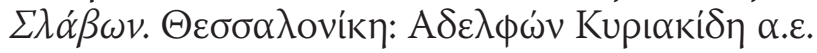

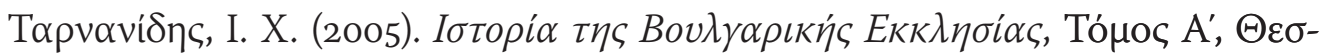

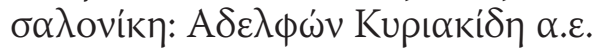

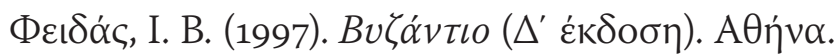




\author{
Radovan Radić
}

Christian Cultural Centre, Belgrade

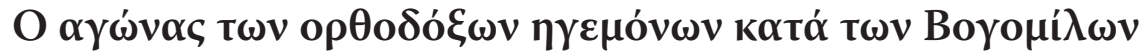

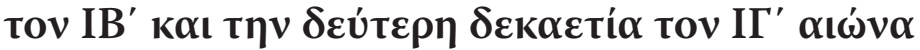

$\mathrm{H}^{\infty}$

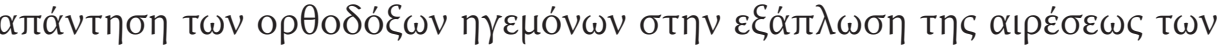

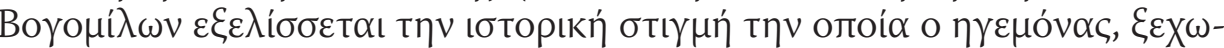

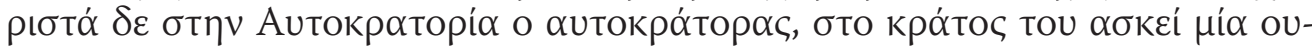

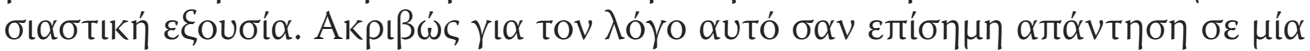

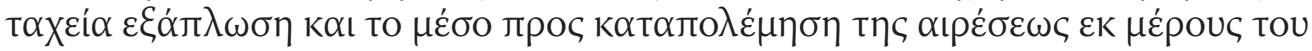

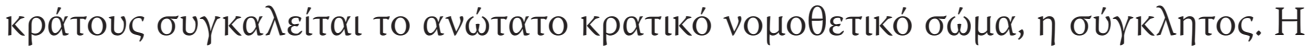

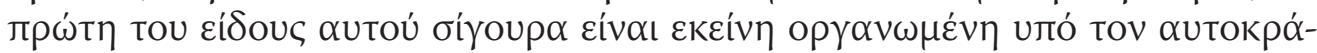

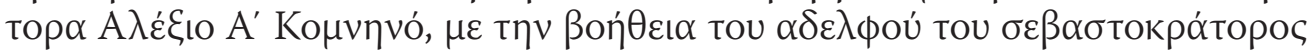

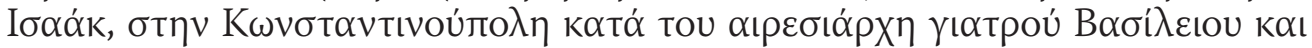

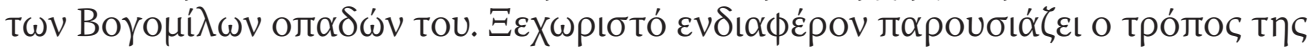

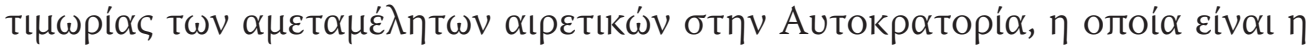

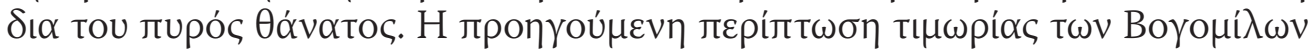

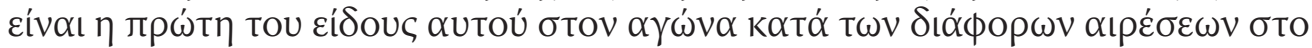

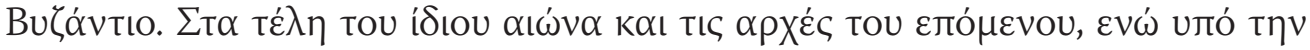

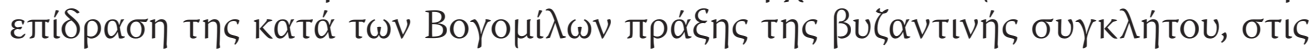

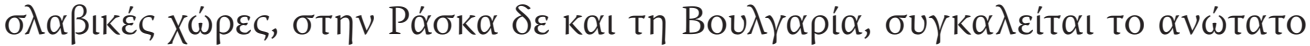

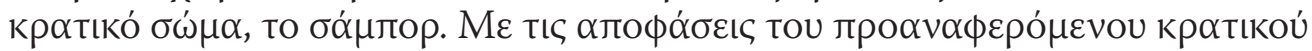

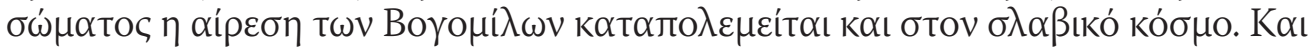

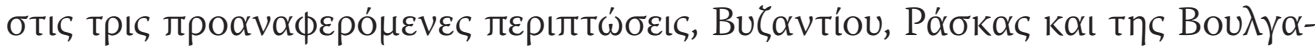

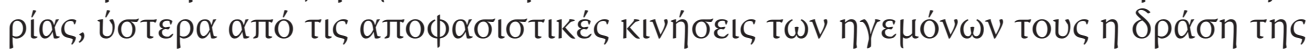

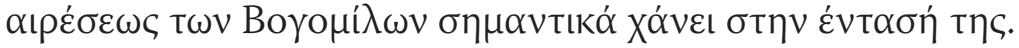

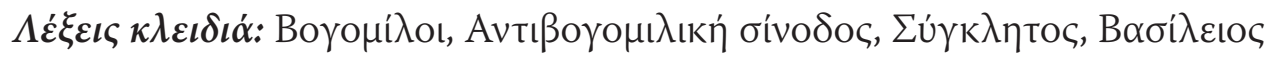
Boүó

Датум пријема чланка: 3. 6. 2015.

Датум прихватања чланка за објављивање: 17. 12. 2015. 